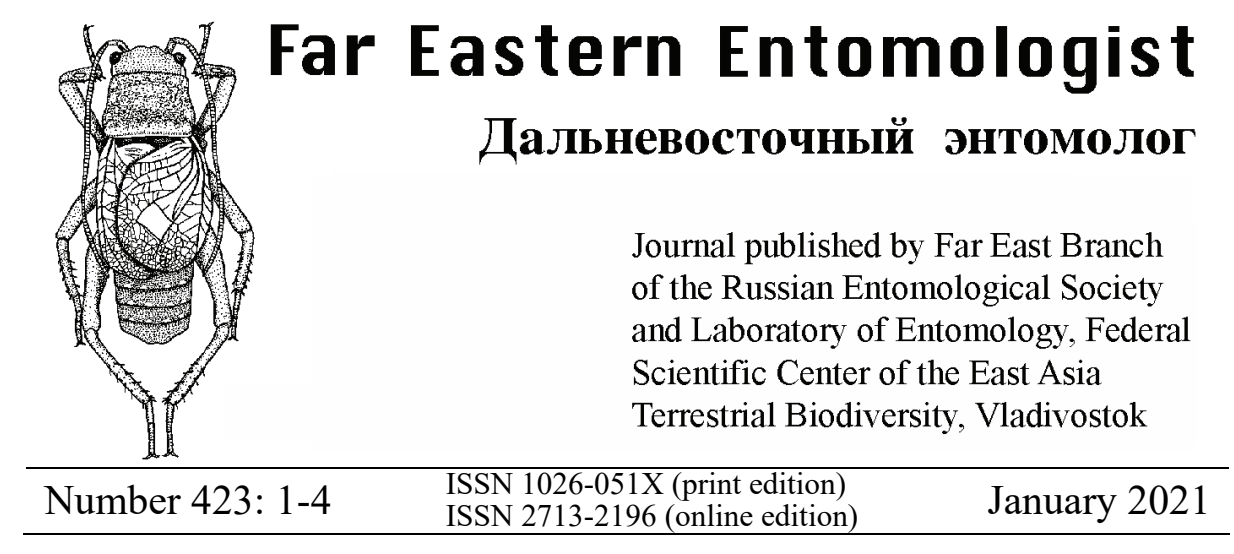

https://doi.org/10.25221/fee.423.1

http://zoobank.org/References/FB4C8485-BEB2-43B9-B2E5-490C39156AB7

\title{
A NEW UNUSUALLY SMALL SPECIES OF THE GENUS THINODROMUS KRAATZ, 1857 (COLEOPTERA: STAPHYLINIDAE: OXYTELINAE) FROM THAILAND
}

\section{Yu. Gildenkov}

Department of Ecology and Chemistry, Smolensk State University, Smolensk, 214000,Russia.E-mail: mgildenkov@mail.ru

Summary. Thinodromus (s. str.) improcerus sp. n. is described from Thailand. New species differs from other species of Thinodromus Kraatz, 1857 by the structure of the aedeagus and by smallest for the known species of the nominotypical subgenus size (body length $2.2 \mathrm{~mm}$ ). New species is characterized by follows: punctation of the head and pronotum more distinct than those of the elytra; the anterior margin of tergites III-V of the abdomen has 4 characteristic deep round depressions.

Key words: Coleoptera, Staphylinidae, Thinodromus, taxonomy, new species, South Asia.

М. Ю. Гильденков. Новый необычно мелкий вид рода Thinodromus Kraatz, 1857 (Coleoptera: Staphylinidae: Oxytelinae) из Таиланда // Дальневосточный энтомолог. 2021. N 423. C. 1-4.

Резюме. Из Таиланда описан Thinodromus (s. str.) improcerus sp. n. Новый вид хорошо отличается от других видов рода Thinodromus Kraatz, 1857 строением эдеагуса, а также самыми мелкими размерами (длина тела $2.2 \mathrm{~mm}$ ) среди 
всех известных видов номинативного подрода. Новый вид характеризуется следующими признаками: пунктировка поверхности головы и переднеспинки более четкая, чем поверхности надкрылий; на переднем крае III-V тергитов брюшка имеется по 4 характерных глубоких круглых вдавления.

\section{INTRODUCTION}

Present paper is a continuation of the author's study of the genus Thinodromus Kraatz, 1857 of the Oriental region (Gildenkov, 2017, 2018a,b, 2019a, b, 2020). New species described below does not belong to the «lunatus» group or any other known species groups of Thinodromus.

This paper is based on the specimens deposited in the following collections: NHMW - Naturhistorisches Museum Wien (Austria); cMG - private collection of Mikhail Gildenkov (Smolensk, Russia).

The dissections, measurements, and drawings were made using a MBS-10 microscope provided with an eyepiece-micrometer and a measuring grid. In the following description, the length to width ratio for the head, pronotum, and elytra is given using standard units: 7 standard units $=0.1 \mathrm{~mm}$; thus 1 standard unit is about $0.0143 \mathrm{~mm}$. The slides of the genitalia were treated with $10 \% \mathrm{KOH}$ and fixed in euparal. Photographs were taken with a Canon EOS 5D Mark III camera and a Canon MP-E 65 $\mathrm{mm}$ objective using the extended focus technology.

\section{TAXONOMY}

Thinodromus (s. str.) improcerus Gildenkov, sp. n.

http://zoobank.org/NomenclaturalActs/A8253E11-07DB-4573-AD21-AF19935CDB4C

Figs $1-4$

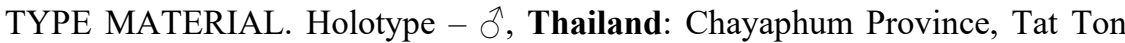
National Park, with label "THAILAND: 27.11.1995 Chayaphum Prov. Tat Ton NP leg. Zettel (30)" (NHMW). Paratype: Thailand, 19, with label "THAILAND Jan. 1989240 km NW Bangkok 110 m, leg. Thielen" (cMG).

DESCRIPTION. MALE (holotype). Length of body $2.2 \mathrm{~mm}$. Dark-brown, legs and antennae yellow-brown. Integument is quite shiny, body with fairly short lightcoloured seta.

Head transverse, with a wide base, ratio of its length (from posterior margin of the head to the anterior margin of clypeus) to maximum width is about $18: 29$. Neck constriction is prominent. Eyes large, convex, occupying almost entire lateral side of head; temples almost indistinct, the head has the largest width in the eye area (Fig. 1). Head surface with clearly, rather finely and dense punctation. Diameter of punctures is about 1.5 times smaller than the eye facet. Distances between punctures are significantly smaller than their diameter, interspaces smooth, shiny (Fig. 1). Antennae rather long (Fig. 1), antennal segments 1-8 elongate; segment 9 
slightly elongate; segment 10 about as long as wide; segment 11 elongate, conical. Last 3 segments more massive and form loose club.

Pronotum heart-shaped, reaches its greatest width after about $2 / 3$ of the length measured from the base, then narrowed (Fig. 1). Ratio of pronotum length to its maximum width is about $24: 31$. Surface of pronotum with clearly, rather finely and dense punctation. Diameter of punctures is about 1.5 times smaller than the eye facet. Distances between punctures are significantly smaller than their diameter, interspaces smooth, shiny (Fig. 1). Base of pronotal disc with distinct horseshoeshaped depression (Fig. 1).
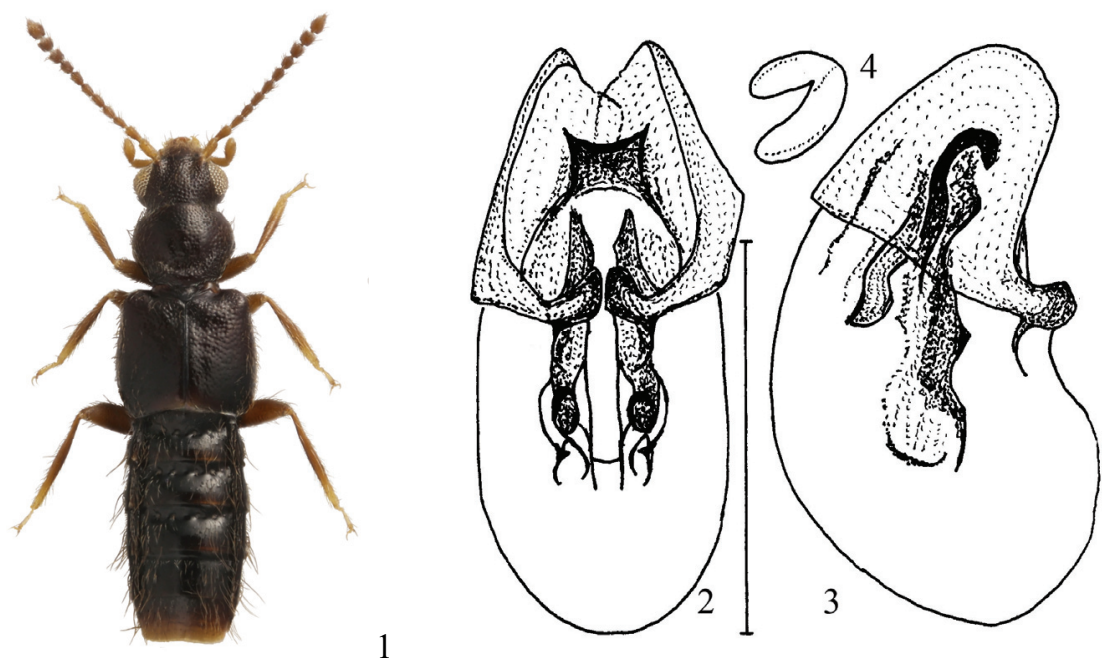

Figs 1-4. Thinodromus (s. str.) improcerus, sp. n. 1 - male body, dorsal view; 2 aedeagus, dorsal view; 3 - the same, lateral view; 4 - spermatheca, lateral view. Scale bars for figs. $2-4=0.25 \mathrm{~mm}$.

Ratio of length of elytra to their combined width is about 38:42. Elytra with rather delicate, rather finely and dense punctation. Diameter of punctures is about 1.5 times smaller than the eye facet. Distances between punctures significantly smaller than their diameter, interspaces smooth, shiny (Fig. 1).

Abdomen with very fine and very sparse punctation, shiny. The anterior margin of tergites III, IV, and V has 4 deep round impressions.

Aedeagus of a characteristic structure (Figs 2, 3).

FEMALE (paratype). Length $2.2 \mathrm{~mm}$. Sexual dimorphism absent, female morphologically is similar to male. Spermatheca as in Fig. 4.

DIAGNOSIS. The species is distinguished by its small size, clear and dense punctation of the head and pronotum and the presence of four deep rounded depressions on the anterior margin of tergites III, IV and V (Fig. 1). Reliably new species is distinguished from all known species of Thinodromus by the structure of the aedeagus (Figs. 2, 3). 
DISTRIBUTION. Thailand.

ETYMOLOGY. From the Latin "improcerus" - "small", the name is associated with small size.

\section{ACKNOWLEDGEMENTS}

The author wishes to thank Dr. Harald Schillhammer (Wien, Austria) who provided available material for this study. I also thank Dr. Kirill Makarov (Moscow, Russia) for preparing the photograph of holotype.

\section{REFERENCES}

Gildenkov, M.Yu. 2017. A review of the Thinodromus lunatus species-group (Coleoptera, Staphylinidae). Zoologicheskii Zhurnal, 96(10): 1165-1180. [In Russian with English summary] DOI: 10.7868/S0044513417100075

Gildenkov, M.Yu. 2018a. A new species of the genus Thinodromus Kraatz, 1857 (Coleoptera: Staphylinidae: Oxytelinae) from China. Far Eastern Entomologist, 356: 17-20. DOI: $10.25221 /$ fee. 356.3

Gildenkov M.Yu. 2018b. Six New Species of the Genus Thinodromus Kraatz 1857, Closely Related to Thinodromus (Amisammus) ripicola (Cameron 1941) (Coleoptera, Staphylinidae: Oxytelinae). Zoologicheskii Zhurnal, 97(11): 1363-1373. [In Russian with English summary] DOI: 10.1134/S004451341811003X

Gildenkov M.Yu. 2019a. New species of the Subgenus Thinodromus Kraatz, 1857 (Coleoptera: Staphylinidae: Oxytelinae), from India and Nepal. Far Eastern Entomologist, 381: 15-20. DOI: $10.25221 /$ fee.381.3

Gildenkov M.Yu. 2019b. Three New Species of the Thinodromus arcuatus Group, Genus Thinodromus Kraatz, 1857 (Coleoptera, Staphylinidae: Oxytelinae), from the Oriental Region. Zoologicheskii Zhurnal, 98(11): 1205-1212. [In Russian with English summary] DOI: $10.1134 / \mathrm{S} 004451341908004 \mathrm{X}$

Gildenkov M.Yu. 2020. Three new species of the genus Thinodromus Kraatz, 1857 from Indonesia and the Philippines (Coleoptera: Staphylinidae: Oxytelinae). Russian Entomological Journal, 29(2): 148-152. DOI: 10.15298/rusentj.29.2.04 